\title{
SHARIA CRIMINAL LAW, ISLAM AND DEMOCRACY IN NIGERIA TODAY
}

\author{
Ikenga K.E. Oraegbunam \\ doi: http://dx.doi.org/10.4314/og.v8i1.10
}

\begin{abstract}
Sharia and Islam constitute one of the key indices in the current Nigerian constitutionalism and democracy project. Although it has made a considerable inroad into the nation's grundnorm, Islamic law still seeks to extend the prongs of its justice system beyond the jurisdictional scope granted it by the 1999 constitution. The effect is that criminal and other aspects of the legal regime have been adopted by most states in nothern Nigeria but not without an affront to the secularity principle that should undergird national affairs. This paper examines the socio-economic and political implications of the extended sharia on human rights of Muslim and non-Muslim citizens. It also seeks to juxtapose the adoption of Islamic criminal law with the role a religion and its laws should play for national integration and social cohesion. The study equally suggests ways by which Nigerian Islamic law and religion would be made to join in winding the wheel of progress of Nigerian democracy. The methodology employed is largely structural-functional and jurisprudential.
\end{abstract}

\section{Introduction}

The relationship between Islam and democracy in the contemporary world is quite complex. This is because the Muslim world is by no means ideologically a monolith. Various Islamic adherents and groups exhibit varied attitudes to popular and modern notions of democracy and its tenets. Esposito \& Voll (2001: n.p.) observe that studies present "a broad spectrum of perspectives varying from the extremes of those who deny a connection between Islam and democracy to those who argue that Islam requires a democratic system". In between the extremes is a position of those who hold that "Islam is a support for democracy even though their particular political system is not explicitly defined as Islamic" (Esposito \& Voll, 2001: n.p.). 
Be that as it may, the Nigerian situation seems to paint a much more complex scenario. Not less than four outlooks can be identified. Firstly, at one end are mainly non-Muslims who believe that application of Islamic criminal ethos and laws beyond the provisions of the constitution would collide headlong with modern democratic principles and multi-religious nature of Nigeria (eg Ubaka, 2000:47-49; Okike, 2000:20-35; Nwabueze, 2001: 91-121). Secondly, the other rung of the ladder is occupied by mainly pious Muslims, for whom the idea of democracy is purely of Western, foreign and secular origin, and has nothing to do with Islamic practice (Makosa, 2007:n.p.). Some of these Islamists are of the view that democracy is a practice that is imposed by Westernizers and secular reformers upon Muslim societies. They often argue that the concept of popular sovereignty on which much of an entire edifice of democracy is built denies the fundamental Islamic affirmation of the sovereignty of Allah, and is therefore a form of idolatry. For this school of thought, the injunctions of Sharia and the provisions of the constitution or any other law are quite parallel, and at the event of any conflict, the former would prevail.

Aside these extremes however, the third group of scholars see compatibility between Islam and democracy. Some of these affirm that under the conditions of contemporary world, democracy can be considered a requirement of Islam. In this connection, the recent adoption of Islamic criminal law by most northern states claims the Nigeria democratic constitution as its source of empowerment and raison d'etre. For instance, Haruna (2003:144) believes that "using a number of the 1999 constitutional provisions, the Governor of Zamfara State assented to the bill establishing the Sharia penal system passed by the Zamfara House of Assembly". In the same vein, Babaji (2007:98) holds that the implementation of Sharia in Northern Nigeria is "as a result of the coming into operation of the constitutionally and democratically elected leaders in Nigeria". Yet there is the fourth group of intellectuals, who maintain that Islam $a b$ initio practises democracy (khilafah) even as the Islamic concept of the term is quite different from the modern notion. Thus, Maududi (1960:29-66) notes that such terms as 'the state', 'sovereignty', 'constitution', 'citizenship', 'rulers', 'legislature', judiciary', and so on, have somewhat different connotations in an Islamic state. 
All these views go to show the multifarious approaches that scholars use in theoretically discussing the relationship between Islam and democracy in Nigeria. However, the real practice of Islam in Nigeria today seems to be controversial and prejudicial to the nation's democratic project. For some time now, the Muslims, predominant in the North, have always insisted on "dipping the Koran in the Atlantic" especially by seeking to introduce full Sharia legal system into all corners of the country. On the other hand, the non-Muslims especially Christians, prevalent in the South, following their religious beliefs and convictions, would not accept to be governed or even affected by Islamic law. The different positions have often resulted to violence, destruction, and death. The scenario painted in this paper is, in addition to the relevant situation in Nigeria, created by the religio- political mayhem in North Africa and many Arab nations today such as Tunisia, Egypt, Libya, Syria, Yemen and so on. Although in most of these Islamic and Islamdominated countries there are protests to unseat draconic and sittight regimes, yet an aspersion is cast by discerning minds on the lopsided and bigoted Islamic notion of democracy. Non-Muslims' lives and properties are still being destroyed in these enclaves, and churches and rights of especially Christians are constantly violated.No doubt,this atmosphere widens the spiral of violence in these areas and environs.

However, this paper seeks to study the implications of adopting a Sharia criminal justice in a multi-religious state and juxtapose the fruits of the study with the basic features of constitutional democracy in Nigeria. In other words, this paper will attempt to respond to these questions: Does application of Islamic criminal law promote the social roles religion is expected to play in Nigerian society as a whole? Can Sharia law with its stringent and harsh penal practices go together with constitutional stipulations? Is it possible to separate religion and state among Islamists? What is the attitude of Islam and its criminal laws to individual rights? Is it proper that religious texts be used as blueprints for the structure of a modern society? In fact, is full Islamic practice in Nigeria compatible with modern democratic principles? The paper is a critical comparative study of the main sources of Islamic law generally and of Sharia penal laws of some Northern states on the one hand and the 1999 
constitution and tenets of democracy on the other hand. A structuralfunctional evaluation of the study in the light of the social functions of religion would be made. The paper will be concluded with some recommendations and suggestions that may belly the ache.

\section{Definition of Key Terms:}

\section{Islam}

In this paper, Islam is seen as one of the three main religions in Nigeria which adherents are predominant in the North. Its teachings are founded on the Koran, life of Muhammad and some other sources ( Ozigbo, 1988:2). An adherent of Islam is called a 'Muslim', which is the active participle of the same verb of which 'Islam' is the infinitive.

\section{Sharia}

Sharia is Arabic word that literally means a drinking place or a path leading to a watering hole (Ubaka, 2000:11; Kenny, 1986:20). The implication is that since water is regarded as a source of life, Muslims claim that Sharia is the fountain of not only earthly but also eternal life. Farlex (2009:n.p.) describes Sharia as a "code of law derived from the Koran and from the teachings and examples of Mohammed". Johnson (2009:n.p.) expands the meaning of Sharia as "inspired not only by Islam and Koran but also by Arabic traditions and early Islamic scholars". In this paper, Sharia is understood as constituting those rules of conduct derived from different sources of Islamic religion and codified into a body of law by relevant legislatures with the intention of getting them enforced through state machinery. It is equally understood as that body of Islamic law as interpreted by the Maliki school of Islamic jurisprudence which is the only acceptable version in Nigerian Islam.

\section{Adoption of Sharia Criminal Justice}

In this paper, 'adoption of Sharia criminal justice' means those attempts by Muslims in Nigeria to widen the scope of application of Islamic law to include the whole of criminal justice system. This is the situation in those Northern states that are today dubbed 'Sharia states'. 


\section{Religion}

There is no generally accepted definition of religion. This is perhaps why Metuh (1987:29-30) regards religion as a "very elusive concept to define". Okwueze (2004:1-2) perceives religion as a social fact. He defines it as "a regulated pattern of life of a people in which experiences, beliefs and knowledge are reflected in man's conception of himself and in relation to others, his social world, the physical as well as the metaphysical world". In this paper, the religious subject is understood as having not only a vertical dimension of relating with the divine but also a horizontal implication of co-operating with the members of the society among whom one finds himself. This is probably why Adibe (2008:116) notes that "religious social life must be within the confines of the higher law of the land where it is established; otherwise it would be antisocial to the setting of the generality of the community which is often pluralistic". It seems that in Nigeria, such a higher law of the land would not be anything different from the constitution.

\section{Society}

Okwueze (2004:4) rightly observes that the term 'society' has become "elastic in modern usage". This means that it can be used in myriad senses. Moreover, just as Okwueze (2004:4) notes that society is "no longer limited to a group of people who are related or who belong to the same profession but now extends to those who live together within a geographical location", the society which this paper refers to is the Nigerian society unless the context states otherwise.

\section{Democracy}

The Oxford Pocket Dictionary of Current English (2009:n.p.) defines democracy as "a system of government by the whole population or all eligible members of a state, typically through elected representatives". Similarly, Wikipedia, the free Encyclopedia (2009:n.p) regards democracy as "a political government either carried out by the people or the power to govern is granted to elected representatives". The term is derived from the Greek 'demokratia' which in turn is coined from two other Greek words 'demos' 
(people) and 'kratos' (rule or power) (Nwodo, 1990; Onah, 1998; Nwuzor, 2002; Kukah, 1999).

\section{Constitution}

In this study, "the constitution" refers to the Constitution of the Federal Republic of Nigeria (C.F.R.N) 1999. By virtue of its section 1 , it is "supreme and its provisions shall have binding force on all authorities and persons throughout the federation". C.F.R.N (1999) states that "if any other law is inconsistent with the provisions of this constitution, this constitution shall prevail, and that other law shall to the extent of the inconsistency be void" (section 1 (3)).

\section{The Role of Religion in Society}

Yinger (1970:7) observes that there is no corner of society in which religious practices do no exist. For him, "religion is an ancient component of human culture which grew out of man and out of which man grew. Smart (1984:3) maintains that "throughout history and beyond in the dark recesses of the human race's earliest cultures, religion has been a vital and pervasive feature of human life. This is corroborated by Giddens (1993:456) who notes that "religion has continued to be a central part of human experience, influencing how we perceive and react to the environments in which we live. Edokobi (2009:239) is equally aware of this fact when he writes that "one of the most common practices of humanity all over the world is the practice of religion". Therefore most authors in Sociology of Religion would always regard religion as co-eval with human society.

However that may be, the religious experience of mankind is by no means monolithic. There are varieties of religious experience (James, 1902). Streng, Lloyd and Allen (1973:v-x) delineate eight different ways of being religious. They include:

Rebirth through personal encounter with the holy, creation of community through myth and ritual, living harmoniously through conformity to the cosmic law, spiritual freedom through discipline or mysticism, attaining an integrated self through creative interaction, achievement of human rights 
through political and economic action, the new life through technocracy and enjoyment of the full life through sensuous experience.

This is perhaps why Madu (2003:43) writes:

During the thousands of years of mankind's history, man's search for God has led down to many path ways. The result has been the enormous diversity of religious expression found world wide.

Consequently, Nigeria is a multi-religious society harbouring Islam, Christianity and Traditional religions among others. In Nigeria, there is an experience of "religious pluralism" which "within the sociopolitical context...." is described by Imo (1990:8) as "the result of social transformations which give rise to people of different beliefs, values and customs being brought together by the forces of history in social relationship. Although Haralambos and Heald (1980:447) hold that religious pluralism "has been seen as a further fragmentation of institutional religion and therefore an evidence of the weakening hold of religion over society", it is still a fact of human experience that as there are individual differences so do they take to different religious pathways.

However, religion as a social institution is not an isolated social fact that is unrelated to any other. It is both a dependent and independent variable. Therefore, religion generally affects the societal structure and social structure affects religion. Religion influences the social units and is influenced by them. No wonder Yinger (1969:265-316) writes of "religious change as both a cause and an effect of social change". In the same manner if it is true as Adogame (1999:22) observes that "all social phenomena within any given group or societies are interrelated", then religion as an indisputable social fact affects the development of a society. Hence, Okeke (2008:1) affirms that "religion is in continual, reciprocal interactive relationship with other social units like politics, economy, the class system, family, law and so on which together constitute the essential ingredients of a human society". It is therefore no wonder that Okwueze (2004:2) rightly observes that "a major concern which 
has emerged in the study of religion is the examination of its relationships with economic, political, cultural and social institutions as well as its diverse functions and dysfunctions in the life of society". It is mainly to this task that the present section is devoted.

Many a scholar has delineated religion as an integrator of human society. Thus Bergson (1935:112-113) finds integration to be an important function of what he calls the "static religion of the closed society". The integrating function of religion however does not pretend to gloss over the fact that religion can be a source of division and rancour. But then, it would seem that such divisive tendencies occur as a result of unhealthy mixture of religion with other things like politics. Hence Nadel (1954:30) insists that religion "holds societies together and contains their structure". Dzurgba (1993:82) similarly observes that "religion has been the most general instrument used in integrating meanings and motivations in social actions".

Religion has also been seen as a promoter of morals. Goldthorpe (1985:203) maintains that "the connection between religion and morals is undeniable though not a simple one". Thus, Edokobi (2002:251) observes that "moral codes derive their force from religion which says that evil must be avoided and good must be done. Edokobi (2002:215) maintains that religion "originates from keeping a distance from the evil".

Studies in sociology of religion have also not failed in revealing a manifold and complex interplay between religion and economy. It was Weber (1968) who called the attention of the sociological community to the intricate connection between protestant Calvinist ethic and the rise of capitalism. Although Weberian theory has been barraged with myriads of criticisms, it is still a fact that religion is not sterile in the face of economic development. It is along this line that Yinger (1969:202) holds that "religion affects the demand side of the familiar supply-demand question". In this connection, it is observed that the church encouraged hard work and discouraged laziness among the converts which attitude led to economic emancipation and empowerment of Nigeria Christians (Agha, 2004:26).

Furthermore, there is no doubting the fact that even though religion can be an effect of social change, society can equally be an 
effect of religious attitudes. Ilori (1993:50) holds that ideas and beliefs "organize experiences and influence that reflective response to the environment that characterizes human behaviour". Again, religion is a factor of educational development. The Christian bible writes of Christ's injunctions to his followers: "Go ye to the ends of the earth and teach all nations (Mt 28: 18-20) it is this command that lies at the basis of establishment of schools by the Church and other religious bodies. Islam also has its ways of promoting education.

Another notable and important function of religion is "social work" or charity work. In any society, there are always people in need and some form of taking care of them. Akukwe (1998:187) maintains that "how this is done is dependent on the people's conception of man and society". Almsgiving, establishment of hospitals, leprosaria and orphanages are some of the ways through which religion performs this role.

Religion is equally an agent of socio-political action. Ehusani (1996:25) notes that "the Church in order to perform its prophetic role should not stand aloof from the socio-political life of its adherents". It must be interested in politics. It is against this backdrop that the Christian Association of Nigeria and the Catholic Bishops Conference of Nigeria have respectively played the role of being the voice of the voiceless especially in the midst of political subterfuge and military misrule that threatened to grind the country to a halt. Hence, Schineller (2002) has compiled the pastoral letters and communiqués of the Catholic Bishops Conference of Nigeria in this regard from 1962 to 2002 under the title The Voice of the Voiceless. In the same vein, Islam is very interested in politics since as Said (2003:190) notes "sharia admits of no dichotomy between private life and public life".

Religion is also a controller of stress. It is a quality response to human problems of loneliness, suffering, death and unhappiness. Thus, the religious teachings on eschatology and after-life are already enough palliative to cope with the stresses. Hood, Spilka, Hunsberger and Gorsuch (1996) have strongly emphasized this role of religion. Gross (1982:4) too affirms this role in his famous dictum: "when misery is the greatest, God is the closest". It is perhaps this point that Marx (1963:11) is making when in regarding 
religion as a social pacifier takes it as an "opium of the people" and the "sigh of the oppressed creature".

Another most important function of religion is conflict resolution. Adamolekun (2002:12) sees "understanding, tolerance, dialogue, interaction and reconciliation as means of resolving conflict in a society". In the same vein, the role of traditional rulers and religious leaders in conflict resolution is well noted. According to Laguda (2002:10), religious leaders are expected to do this by "using virtues of their religions to preach peace and harmonious coexistence among conflicting interests".

Suffice it then to summarize the functions of religion in a society with the outline of the functions given by Edokobi (2002:248-252). He gives eight functions of religion. They include religion as the supplier of ultimate knowledge, religion as means of coping with life, religion as the giver of courage, religion as the giver of purpose to life, religion as providing answers to questions of death, religion as enhancing the moral codes, religion as a social stabilizer, and religion as the pacifier.

Nevertheless, the above roles of religion do not in any way detract from the fact that religion can also be a source of social dysfunction (Kenny, 1984). "Religion" too as Okwueze (1998: 136) notes "has the potential of introducing cultural crises". Okwueze (1998: 142) gives a reason for this:

The problem with religion is that being the substance of culture, religion as components of culture is a cultural propaganda, which admits of no objectivity in assessing the opposing culture in a manner that will enable it see what is good and what is not good. Every religion sees any other culture apart from the one it represents as a conquerable battle-field. This largely explains the attitude of the first Christian missionaries towards African cultures....

Besides, replete is instance around the world where religious intolerance and bigotry lead to violence, bloodshed and indeed death. 
Some of these crises lead to unprecedented cases of schism. In Christianity, for instance, Obiora (1998:21-44) makes a role call of 1267 assemblies that regard themselves as Churches. Most of the breakaways are engendered by struggle for money and power. Even within the same religion, cases of inter and intra denominational rancours and sectarianism abound which often scandalize nonadherents.

The crises in the Middle East, the Sudan and various acts of terrorism, for instance, are not devoid of religious underpinnings. No wonder Ekwunife (1992:5) observes that "religion can be both an integrative and divisive factor in any society". He notes that "when the divisive elements of religion are not properly handled and brought under strict control, they create tensions and unrest in a society". Moreover, some religions habour within themselves seeds and actual practice of discrimination among its adherents. Gender inequity, patriarchalism, stratification, caste system, and other vices such as indoctrination and proselytism dot the practical terrain of many a religion. Yet in spite of these anomalies that are often attributed to the human face of religion, religion, as Oraegbunam (2005:3) notes, is still "a cause of various social changes and development"

\section{Adoption of Sharia Criminal Justice and the Role of Islamic Religion in Nigerian Democracy: A Test Case}

The period from 1999 till date has witnessed a dramatic turn of events in the enforcement of Islamic law in Nigeria. Following a new interpretation of the CFRN 1999, most northern states led by Zamfara made certain laws, repealed some, and amended some others. By these they established Sharia courts and vested them with not only the entirety of civil but also criminal jurisdictions. Zamfara state, for instance, arrived at these by way of five laws. They include: (a) Sharia Court (Administration of Justice and Certain Consequential Changes) Law No. 5, 1999; (b) Sharia Court of Appeal (Amendment) Law No. 6, 2000; (c) Area Courts (Repeal) Law No. 13, 2000; (d) Sharia Penal Code Law 1999; (e) Sharia Criminal Procedure Code Law No. 18, 2000. 
In that order, the first law provides for the establishment, composition and jurisdiction / grades of Sharia courts, and makes general provision for the administration and implementation of Islamic law in the state. The second provides for the jurisdiction of Sharia Court of Appeal of the state to hear and entertain appeals from the decisions of the Sharia courts in both civil and criminal matters decided on Islamic law. The third legislation repealed the Area Courts Law in the state and makes transitional provisions for the take off of Sharia courts. The fourth makes provision for the substantive Sharia Penal Law and the criminal law to be applied in the state. In other words, the law codifies the offences in their classifications along with the punishments stipulated therefor. The last one provides for the rules of practice and procedure to be followed and applied by the Sharia courts established in the state in their exercise of criminal jurisdictions and in the enforcement of Sharia Penal Code Law. It is also noteworthy that some other eleven northern states have long since followed suit in imitation of Zamfara State, and many of which have copied almost word for word the Zamfara laws. Despite the controversies generated by this application of Islamic criminal law, the justice system has continued to operate in most of Northern Nigeria. Punishments such as amputation, lapidation, stoning to death, crucifixion and so on still attach to Sharia offences in the North. Although only Muslims have been subjected to the jurisdiction of Sharia courts so far, yet experiences in Islamic countries show that there are potentials for extending the judicial practice and coverage to adherents of other religions.

But the above Islamic practice has enormous implications for the role of religion in Nigerian society. Hence, studies are replete with discussions on contribution of religion in the integration of society, promotion of morals, initiation of social change, economic growth, educational development, social work and charity, sociopolitical nation, conflict resolution, interpretation of man's environment, definition of values, control of stress, and guide to eternity (Crews, 1986; Okwueze, 2004; Agha, 2004; Achunike, 2004; Ugwu, 2004; Oraegbunam, 2005; Okeke, 2008; etc). Abdullah (2003:6) succinctly outlines some of the specific contributions of Islamic Sharia to human society, namely; 
(1) Eradicating poverty and creating conditions for full employment and high rate of economic growth through proper planning and building necessary physical and social infrastructures;

(2) Promoting stability in the real values of life;

(3) Maintaining law and order, ensuring social security and economic justice;

(4) Fostering equitable distribution of income; and

(5) Wealth.

This section of our study is tasked with the evaluation of the role, which Islamic practice in Nigeria through the adoption of Sharia criminal justice plays in the development, or mal-development of Nigerian democratic society.

Let us begin with the religious function of integration. It goes without saying that the recent adoption of Islamic criminal law in most of northern states serves as a uniting factor among Muslims in Nigeria irrespective of sectarian differences. If not for anything, the adoption is perceived as yet another win in a jihad against nonMuslims especially Christians. This is in addition to the win over the fight for the constitutional establishment of Sharia Court of Appeal in both the 1979 and 1999 constitutions. Thus, there is a proper integration of Muslims who even as strange bedfellows are nonetheless united in the fight over common enemies. Surely, countable are Muslims, if any, who oppose the introduction of Sharia criminal system even if it is oppressive to them.

But this integrating role of Islamic religion is quite inapplicable in relation to Nigerian democratic society as a whole. Raising discontent among and discrimination against non-Muslims, the adoption of Sharia criminal law tends to be divisive and chauvinistic( Byang,1988; Marshall, 2002). Already criminal Sharia practice has raised serious problem about National Youth Service scheme aimed at uniting Nigeria (Nzomiwu, 2000:3). Thus, it is not uncommon to observe that many corp members sent to work in the Sharia-implementing states develop cold-feet or go there with grudges. The adoption is certainly an obstacle to the realization of Nigerian federal union. This is because the enforcement of criminal 
Sharia impinges on the citizenship rights conferred on membership in the federal union, namely, the right to move about freely throughout the territory of the union, and to live wherever one chooses without molestation based on his religious affiliation (Constitution 1999, SS. 41 (1) \& 42), the right to earn livelihood in his chosen place of residence by means permitted by law, and the right to be treated alike by the state with other citizens. Therefore, there is no doubt that any action by a state government violating these citizenship rights through the enforcement of Sharia criminal law would have the effect of expelling from the state a non-Muslim Nigerian citizen who, for religious or other reasons cannot live under the strict injunctions of and punishments prescribed by the Quran. These include injunctions against operating a hotel or a drinking place, the consumption of alcoholic drink, and certain modes of dressing which are not necessarily forbidden by the non-Muslim's religion. The argument that the non-Muslims are subject to a different criminal law within the same geographical jurisdiction does not convince anyone about the effect of the adoption on citizenship rights of non-Muslims. Hence, even though Sharia criminal justice may foster brotherhood among Muslims, it is still inimical to national unity. This is a major defect of Sharia application and praxis in Nigeria today. Besides, sharia law does not regard all citizens as equal before the law. This is quite illustrated in the real distinction in Islam drawn among 'house of Islam', 'house of war', and 'people of the book'.

Closely related to the above discussion is that of the role of religion in effecting economic growth. There is no gainsaying that most of the functions assigned to Sharia by Abdullah (2003) as enunciated above centre around economic development. Keffi (2003:207-227) observes that the implementation of the socioeconomic aspect of Sharia has improved the quality of life of Muslims and non-Muslims in Zamfara State. What Keffi regards as the implementation of socio-economic Sharia include loan disbursement, provision of social amenities, increase in wage, security, establishment of social welfare scheme, and so on. We however observe that Sharia system is not necessary to put all these in place. Indeed all these are fruits of good governance, Sharia or no Sharia. Perhaps what the criminal aspect of Sharia has been able to 
entrench in the minds of citizens through its stringent penalties is fear and deterrence, and invariably pseudo-security of life and property. Yet it has affected negatively the economic life of the relevant states and that of the entire nation. For one thing, Sharia is not in sympathy with modern economic revolution modeled, as it were, on capitalism and profit motif. The banking system is directly affected as its inner logic of interest accumulation is outlawed as usury by strict Sharia. Moreover, dealers on those commodities like alcohol and certain meats, for instance, trade on which is criminalized by Sharia would be forced to relocate with the attendant economic hazards. This Sharia practice triggers off a debate on whether the value added tax (VAT) tagged on those commodities sold in non-Sharia states will ever be used on the development of the Sharia-implementing states. Certainty, the application of Sharia criminal justice may not create the enabling environment that would attract foreign investment needed today for development in this era of globalization. The result is that the economic life of the Sharia states and its consequences for the nation would leave much to be desired.

More so, the role of Islamic criminal law as it affects morality is worth giving attention. Amucheazi and Onwuasoanya (2008:176) regard the introduction of Sharia codes in Nigeria as "means of enforcement of morality". This is perhaps true as most of the offences codified in the codes are clearly within the realm of morality. Adultery, fornication, sodomy, rape, bestiality, stealing, homicide, incest, abortion, and so on are instances of immoralities that are criminalized by the Sharia codes. However, the Sharia codes are not isolated in this regard. Both the Criminal Code of the southern states and the Penal Code of the remaining northern states contain to the relevant extents offences that are clearly molded from the moral clay. What is however problematic is to what extent would immoralities be raised to the status of crimes? No doubt, a school of jurisprudence is of the view that certain acts though immoral should be outside the purview of legal consideration; instead they should precisely as strictly moral issues be left to the rumination of individual consciences. Lloyd (1991:60) argues thus: 
There may be fields of human activity where the law deliberately prefers to abstain from supporting the moral rule because it is felt that the machinery is too cumbersome to engage upon the particular task and that more social evil may be created than prevented by its intervention.

Surely, questions of sexual morality / immorality belong to these fields. This explains why adultery and prostitution, for instance, are not created offences in some criminal statutes like the Criminal Code of the southern states. Even in jurisdictions like some states in United States of America where adultery is treated as a crime, the law is virtually a dead letter and so tends to do harm by bringing the law generally into disrepute (Lloyd, 1991:60). Again, it is observed that much of the argument propounded in America in 1957 by the Wolfenden Committee urging that the offence of homosexual relations between consenting adults in private be removed from statute books, was based on the belief that such a law is exceedingly difficult to enforce, and when enforced is likely to do more harm than good by encouraging other evils such as blackmail (Lloyd, 1991:60). Furthermore, the libertarian philosophical position, traceable to the English utilitarian thinker John Stuart Mill is of the view that law should not intervene in matters of private moral conduct more than necessary to preserve public order (cited in Stumpf, 1993:373). In other words, there is a sphere of morality that is best left to the whims of private conscience.

Be that as it may, the above reasoning is not meant to hold that law and morals have no relations whatsoever. Indeed, they have strong relations described, as it were, as two intersecting circles whereby the part inside the intersections represent the common ground between the two spheres and the parts outside them denote the distinctive realms in which each holds exclusive sway (Lloyd, 1991:57). In this way, under relevant situations, law and morality reinforce and supplement each other as part of the fabric of social life. Moral codes by recognizing that men ought generally to refrain from certain acts, supplement the force of law that equally forbids them. Again, the moral reprobation which such acts inspire is reinforced by criminal and other sanctions imposed by the law. 
There is no doubt that it is this latter interest that Sharia Penal Codes seek to promote. This is particularly so as Islam does not entertain a caesura between religion, law and morality (Ahmad, 1974:9). Yet there is the need to recognize such distinctions in the light of the multi-religious, multi-cultural and secular Nigeria. Certainly, criminal law is an aspect of public law. It is all about protecting the society and the common good. As such it should concern itself with acts that directly cause public opprobrium. Adultery, incest and sodomy between consenting adults though clearly viewed with consternation, albeit morally, are not part of those acts that breed direct public disharmony. Creating them offences, as do the Sharia Penal Codes is not only to blur the distinction between law and morality but also to construct a blockade against the exercise of human free will. Perhaps, this is why the biblical St. Paul holds that "a person is justified by faith and not by doing what the law tells him to do" (Romans 3: 28) (cf also Onwukeme, 2010:330-352).

Furthermore, the adoption of Sharia criminal law in Northern Nigeria is no less a socio-political strategy. There is no gainsaying that religion has been used to influence socio-political action. In Christianity, liberation theology has exercised a no mean influence especially in the politics of Latin American countries. In Nigeria, some powerful communiqués from the Bishops' conferences have made the government to either rescind or adopt certain policies. Same can be said of homilies and sermons in Churches and Mosques. The role of Justice, Development and Peace Commission (JDPC) of the Catholic Church in the development of Nigeria politics is enormous. (Achunike, 2004:131-141). Similarly, the adoption of Islamic criminal law is part of the agenda of governance in the North. It was even seen as aspect of the dividends of democracy to the Muslim citizens of the core Northern states. Provision of security, protection of life and property, respect for fundamental rights and sundry social benefits are regarded as the aim of the application of Sharia criminal law. But the adoption of Islamic criminal law has become so suffused with politics that the scenario has earned it the appellation, "political Sharia". It seems it is a strong political campaign point made as promises by political office aspirants. Perhaps this is an explanation for the speedy manner the adoption spread like a harmattan bush fire among the core 
northern states. But like most political campaign promises in Nigeria, recently not much has been done other than the adoption in spite of its potentialities. Far from agreeing with Obasanjo that "Sharia would die a natural death", it is our view that the adoption of Sharia criminal law is more political than religious.

Another serious area where Islamic religion through the adoption of Sharia criminal justice system has influenced the Nigerian society is that of conflict resolution. By the establishment of Sharia courts as official institution for resolution of disputes, Islamic practice in Nigeria seeks to contribute to national peace and development. This intention may be realized more in questions of personal and civil jurisprudence that concern Muslims only. The case may however be different in issues of criminal justice. Crime is an offence against the state, which in Nigeria is made up of citizens of different religious, ethnic, political and cultural affiliations. Adopting a particular religion's law of crime may be antithetical to peace-building. This is the source of controversy over the adoption of Islamic criminal justice system by Zamfara and other eleven northern states. Rather than resolve conflict, it breeds conflict and discontent. Because issues of crime touch the dignity and life of the human person for which presumption of innocence of the accused and other procedural guarantees are provided for in the 1999 Constitution (s. 36(1)-(2)), such a wholesale application of a religions law of crime especially without ensuring proper adjectival procedure would indeed breach the citizens' right. No doubt, the multiplier effect would be disastrous to national harmony and peace. This denial of fair hearing rights is evidenced in some Sharia criminal cases that were treated by some lower Sharia courts in the immediate post-adoption era. No wonder the cases of Commissioner of Police Sokoto State v. Yakubu Tudu \& Safiyatu Tudu (unreported, Case No. US C / GW / CR / F1 / 10/ 01), and Commisioner of Police Katsina State v. Lawal Kurami \& Anor (unreported, Case No 9 / 2002) in which decisions denying the rights of the relevant parties were upturned at the appeal especially as a result of the hues and cries from national and international communities.

Furthermore, it may be germane to say a word or two on the relation between Sharia law and educational development in Nigeria. 
The Sharia Islam has indeed made some contributions to both formal and informal education. In Nigeria, the establishment of Koranic schools for the learning of Arabic language and Islamic studies is testimony to this fact. Too, other forms of school education structures have been put in place through the efforts of government. Nevertheless, some aspects of sharia regime need be reformed so as to maximize the profits of modern educational facilities. The Islamic negative attitude to co-education is a case in point. In spite of what might be perceived as providing an occasion for sexual immorality among young boys and girls, the emotional and psychological development of the teenagers that is mostly derived from boy-girl association is thrown over board by anti-co-education policy. We suggest that this stand need be re-examined especially as mixedgender education is inevitable in tertiary institutions. Besides, the anti-co-education policy seems to infringe on the students' right to association that is well enshrined in section 40 of the 1999 Constitution. Equally needed to be checked is the anti-western education pathos that dots the Islamic attitude in Nigeria today. This is surely the gamut of the recent Boko Haram saga in which many lives and property were destroyed. Needless to say is that western education civilization constitutes to a great extent one of the indices of the development of the North. Establishment of modern Medicare, university education, electricity, good road network, pipeborne water system, and mechanized agriculture are all fruits of western education. It therefore follows that anti-intellectualist tendencies inherent in Islam generally should be put in proper perspective.

One other issue that requires to be considered is the practice of social work in Islam with particular reference to the concept of Zakat (almsgiving). Almsgiving generally is a common denominator in most major religions - Christianity, Hinduism, Judaism, Buddhism, and so on (Hardon, 1968:15). But in Islam, Zakat occupies a prominent position as it is raised to the status of a mode of worship. Payment of Zakat is indeed a religious duty that awaits a Muslim worth the name. It is to be encouraged in favour of the less privileged provided the benefits are not exclusive to Muslims. Care should also be taken to see that the practice does not encourage laziness on the part of the beneficiaries., 
Finally, precisely as a religion, Islam generally is a seeking for the face of God. It interprets the human environment for the adherents and guides them unto eternity. Islam proclaims itself a religion of peace. It should therefore seek to maintain peaceful coexistence and harmonious living both among its adherents and those of other religions. True, the Islamic community (ummah) is one and indivisible entity not given to national boundaries. Yet, the rights and sensibilities of members of other religions in the immediate surrounding should be taken into consideration. Islam in Nigeria can still guide its members unto divine bliss without adopting a Sharia law beyond the provision of the national constitution, which is the common charter for national unity and harmony. Every person is adorned with some rights but one's exercise of such rights stops where another's begin. In order to achieve this, the recommendations discussed hereunder should be strictly adhered to.

\section{Recommendations}

In the light of the above problems associated with the adoption of Islamic criminal justice in Nigeria, especially in the North, this paper makes the following suggestions and recommendations:

Sharia and Islam should be reformed. Socio-historical change and evolutionary spirit make it inevitable for Sharia Islam to read the 'signs of the time'. Accordingly, Islam needs to reform its laws in line with the modern needs (Adigwe, 2000).

In the same line with need for legal reform, Nigerian Islam must undergo a socio-religious rebirth. Giddens (1993:387) observes that "religion is a social institution". As such, it enhances the social life of the society that practises it. Therefore Islamic religion in Nigeria must learn to co-exist with other religions. Christians and adherents of other religions must be allowed to practise their faith without hindrance.

In a multi-religious state like Nigeria, common sense demands that separation of religion and politics seems to be the reasonable safe ground (Kukah, 1993).

It is really regrettable that Islam had been propagated along with the Arab culture (Arabization)(Stamer, 1995:13) of violence and private vengeance. It may therefore be necessary to inculturate Islam, like in 
the days of the Ummayads, (Nzomiwu, 1989:50) in such a way that by shedding the Arab garb, one can be authentically Nigerian and authentically Muslim.

Islamic religion in Nigeria needs to employ a little bit of rationality into its manner of operation to curb fanaticism (Chidili, 1998). It is by that that the Nigerian democratic ideals will still be in tact irrespective of Islam and Sharia.

For democracy to survive in Nigeria, adherents of Islam need to read beyond the letters of the Sharia and know that followers of other religions also have their laws.

For the sustenance of democracy in Nigeria, there is an urgent need for government to maintain a neutral posture (Ryu, 2009; Li-ann, 2009; Omotola, 2009) with regard to all religions in Nigeria.

For the growth of democracy in Nigeria, Islam and its Sharia should be aware of the multi-religious and religious pluralistic nature of Nigeria (Odey, 2000:45) and consequently respect the fundamental right to religious freedom of other believers.

There is an urgent need for a national dialogue in which religionoriented problems will, among other things, be in the agenda. This type of dialogue, according to Chiegboka(2004:139) "will give the Nigerian citizens in a secular state, a future of peace, unity and progress".

Apart from national dialogue, it may well be appropriate to often organize inter-religious dialogues in view of mutual understanding and peaceful co-existence.

One of the cardinal principles of any democracy is that of the rule of law (Dicey, 1959). Therefore, it is necessary that Nigerian Islam adhere to the constitutional restriction of Sharia enforcement to its personal aspect.

It is necessary that every Nigerian, be he governed by Sharia or by any other law, should develop some sort of patriotic sense (Nze, 1998) in pursuance of the success of Nigerian democratic projects.

\section{Conclusion}

Nigeria is a multi religious country in which every citizen should be reasonably allowed to practise his faith. Although Sharia is claimed to be essential to Islam and Muslims have a right to it, yet the 
operation of Sharia law must stop where the right of a non-Muslim begins. Islam is in need of reformation even as other religions always undergo some form of reform. What obtains in the golden age of Islam should not necessarily be the yardstick for subsequent generations. The world is changing and Islam must read the signs of the time.

Again, the question of religious freedom has to do with the very nature of man. And since every revelation is received according to the manner of the receiver, the revelation and reception of Sharia should be re-examined in the light of the free nature of man. Man is created free, and he is free to worship the way he likes or even not to worship at all. The future of Nigerian democracy would always be bleak unless Islam comes to terms with the fact that its monolithic culture has long since been replaced by modern pluralism. This is perhaps why the Constitutions of the Federal Republic of Nigeria limit the operation of Sharia to its "personal" dimension. It follows that any attempt to widen the scope of Sharia enforcement to its criminal and penal jurisdictions will certainly truncate the Nigerian democracy. 


\section{References}

** This is an edited version of a paper presented to the Department of Religion and Cultural Studies of the University of Nigeria, Nsukka on $1^{\text {st }}$ December, 2010. It was read under the title, "Adoption of Islamic Criminal Law in Nigeria: A Critique of its Religious Role in the Nation's Constitutional Democracy (1999-2010).

Abdullah, S.Y.(2003). "Priorities in the Establishment of the Sharia System in Nigeria" in

Oseni, Z.I.(ed.). (2003). A Digest on Islamic Law and Jurisprudence in Nigeria.

Auchi: Darun - Nur, pp.6 - 13.

Abikan, A. I. (2003). "Constitutional Impediments to the Total Enthronement of Sharia in Nigeria" in Oseni, Z. I. (ed.) (2003).

A Digest of Islamic Law and Jurisprudence in Nigeria, pp. 164163.

Achunike, H. (2004). "Developing Nigeria through Justice, Development and Peace Commission of the Catholic Church" in Okwueze M. I. (ed.). (2004). Religion and Societal Development: Contemporary Nigeria Perspectives. Lagos: Merit International Publications, pp. 131-141.

Adamolekun T. (2002). "The Principles of Conflict Resolution and Peace Making in Christianity". Unpublished NASR Annual Lecture Paper, B.S.U Makurdi.

Adegbite, A. (2000). "Sharia in the Context of Nigeria" in Committee of Concerned Citizens (CCC) (2000). The Sharia Issues: Working Papers for Dialogue. Lagos: Academic Press Plc.

Adibe, G. E. (2009). Igbo Issues: Values, Chi, Akala Aka, Ikenga, Magic, Agwu, and Manipulation of Divinities. Onitsha: Mid-field W. A Ltd.

Adigwe, H. A. (2000). "The Rights of Muslims in Nigeria to Sharia" in German Alumni News Letter, vol. 7, Sept. 2000.

Adogame, A. (1999). "Religion and Economic Development in Nigeria" in The Nigeria Journal of Economic History. No. 2, pp. 22-45.

Agha, U.A. (2004). "Christian Missionary Work and Development of the Nigerian Nation" in Okwueze....pp. 120-130.

Ahmad, K. (1974). Islam: Basic Principles and Characteristics, Leicester: The Islamic Foundation.

Ahmed, A. B. (2003). "Administration of Islamic Criminal Law and Justice in a Constitutional Democracy: Problems and Prospects" in Ezeilo, J. N., Ladan, M. T. \& Afolabi-Akiyode, A. (eds.) 
(2003). Sharia Implementation in Nigeria: Issues \& Challenges on Women's Rights and Access to Justice. Enugu: Women's Aid Collective \& others, pp. 164-176.

Akukwe, F. N. (1998). "Social Work in Africa: A Quest for Reorientation" in Oguejiofor, J. D. (ed.) (1998). Africa: Philosophy and Public Affairs. Enugu: Delta Public Nigeria Ltd.

Amucheazi, O. D. \& Onwuesoanya, C. (2008). The Judiciary, Politics and Constitutional Democracy in Nigeria (1999-2007). Enugu: Snaap Press Ltd.

Babaji, B. (2007). "Constitutionalism, Democratic Governance and Sharia in Nigeria" in Ahmadu Bello University, Zaria Journal of Islamic Law . vol.iv-v, pp.98-120.

Bergson, H. (1935). The Two Sources of Religion and Morality. New York: Henry Holt \& Co.

Byang, D. (1988). Sharia in Nigeria: a Christian Perspective. Jos: Challenge Publishers.

Chidili, B. (1998). "Religious Fanaticism" in West Africa Journal of Ecclesial Studies (Wajes), vol. 4.

Chiegboka, A. B. C (2004). "Sharia and National Stability in Nigeria" in Unizik Journal of Arts and Humanities, vol. vi.

Constitution of the Federal Republic of Nigeria 1999.

Crews, F.C. (1986). Ultimate Questions: A Theological Primer. New York: Paulist Press.

Dicey, A. V. (1959). Introduction to the Study of the Law of Constitution. $10^{\text {th }}$ Ed. London:

Macmillan.

Dzurgba, A. (1993). "The Positive and Negative Functions of Religion in Society" in Ekponobi, E. (ed.) (1993). Essays in Comparative Religion. Awka: Doxa Academic Productions.

Edokobi, A. C. (2002). "Religion" in Egbu, N. \& Edokobi, A. C. (eds.). (2002). Sociology: An Introduction. Enugu: Oktek Publishers.

Ehusani, G. O. (1996). A Prophetic Church. Ibadan: Intec Printers Ltd.

Ekwunife, A. N. (1992). Politics and Religious Intolerance: the Nigerian Experience. Enugu: Snaap Press Ltd.

Exposito, J. L. \& Voll, J. O. (2001). Islam and Democracy. Retrieved on 9/5/2009 from http://www.neh.gov/news/hunmanities/200111/islam.html.

Farlex, P. (2009). "Sharia" in The Free Dictionary on Line. Retrieved on 23/12/09 from http://www.thefreedictionary.com/sharia.

Garner, B. A. (ed.) (1999). Black's Law Dictionary, $7^{\text {th }}$ Ed. Minnesota: West Group. 
Gibb, H. A. \&. Kramers, J. H (ed). (1953). Shorter Encyclopedia of Islam. Leiden: E. J. Brill.

Giddens, A. (1993). Sociology. Oxford: Polity Press.

Goldthorpe, J. E. (1985). An Introduction to Sociology. London: Cambridge University Press.

Gross, L. (1982). The Last Jews in Berlin. New York: Simon and Schuster.

Haralambos, M. \& Heald R. M. (1980). Sociology: Themes and Perspectives. New Delhi: Oxford University Press.

Hardon, J. A. (1968). Religions of the World. New York: Image Books.

Haruna, B. A. (2003). "The Application of the Sharia Penal System: Constitutional and other Related Issues" in Ezeilo, J. N., Ladan, M. T. \& Afolabi - Akiyode, A. (eds.). (2003). Sharia Implementation in Nigeria: Issues \& Challenges on Women's Rights and Access to Justice. Enugu: Women's Aid Collective \& others, pp. 138-163.

Hood, R. W., Spilka, B., Hunsberger, B. \& Gorsuch, R. (1996). The Psychology of Religion. New York: The Guilford Press

Ilori, J.A. (1993). Religion and Social Change: An African Perspective. Zaria: Adams Press.

Imo, O. C. (1990). Religion and Democratization in Nigeria. Unpublished NASR Annual

Conference Paper, Benue State University Makurdi.

James, W. (1902). The Varieties of Religious Experience. New York: The Modern Liberty.

Johnson, B. (2009). "Sharia" in About.com World News. Retrieved on 23/12/09 from http://worldnews.about.com/od/qt/9/sharia.htm.

Keffi, S.U.D.(2003). "Improving the Quality of Life of Muslims through the Implementation of the Socio-economic Aspects of Sharia in Nigeria" in Ezeilo, J. N., Ladan, M. T. \& Afolabi Akiyode, A. (eds.). (2003). Sharia Implementation in Nigeria: Issues \& Challenges on Women's Rights and Access to Justice. Enugu: Women's Aid Collective \& others, pp.207227.

Kenny, J. (1984). "Religious Movements in Nigeria, Divisive or Cohesive? Some Interpretative Models" in Orita: Ibadan Journal of Religious Studies, vol. xvi. 2.

(1986). "Sharia in Nigeria: A Historical Survey" in Bulletin of Islam and Christian-Muslim Relations in Africa (BICMURA) 4: 1 . 
Kukah, M. H. (1993). "The Politicization of Fundamentalism in Nigeria" in Gifford, P. (ed.). (1993). New Dimensions in African Christianity. Ibadan: Sefer Books Ltd.

(1999). Democracy and Civil Society in Nigeria. Ibadan: Spectrum Books Ltd.

Li - ann, T. (2009). Religion \& the Secular State. Retrieved on $7^{\text {th }}$ April 2010 from http://www.we-are-aware.sg/2009/05/28/religion-thesecular-state/.

Lloyd, D (1991). The Idea of Law. London: Penguin Books.

Madu, J. E. (2003). The Paradox of the 'One' and the 'Many' in Religion. Nkpor: Globe Communications.

Makosa, B. M. (2007). "Nigeria: Between Democracy and Islam" in Ohmy News. Retrieved on 23/12/09 from http://english.com/articlesview/article_view.

Marshall, P. (2002). Sharia Law Threatens Nigeria's Stability. Retrieved on 20/4/10 from

http://www. domini.org/openbook/nigeria 20020327.htm.

Marx, K. (1963). Das Kapital. Berlin: G. Duhaze.

Maududi, S.A. (1960). Islamic Law and Constitution. Lahore: Islamic Publications Ltd.

Metuh, E. I. (1987). Comparative Studies in African Traditional Religion. Onitsha: Imico Publishers.

Muslehuddin, M. (1986). Philosophy of Islamic Law and the Orientalists (Rev. Ed.) New Delhi: Longmans.

Nadel, S. F. (1954). Nupe Religion. London: Routledge \& Kegan Paul Ltd. Njoku, P. N. (2005). Nigerian Federation: the Socio-political Impetus for a Constitutional Order. Owerri: Cel-Bez Printing and Publishing Company.

Nwabueze, B. (2001). "Freedom of Religion: the Religious Neutrality of the State under the Constitution and the Sharia Controversy" in Bulletin of Ecumenical Theology, vol 13. pp 91-121. -(2000). "Constitutional Problems of Sharia" in CCC (2000). The Sharia Issues: Working Papers for Dialogue. Lagos: Academic Press Plc.

Nwodo, C (1990). "The Concept of People in a Democracy" in IkengaMetuh, E. \& Ojoade, O. (eds.) (1990). Nigerian Cultural Heritage. Onitsha: Imico Publishes pp. 177-187.

Nwuzor, A. (2002). Education for Democracy in Nigeria. Enugu: Future Tech Publishers.

Nze, C. (1998). Patriotism: A Cultural Emanation. Onitsha: Veritas Press and Public Co. 
Nzomiwu J..P.C. (1989). The History and Message of Islam, Awka: MeksUnique Publishers.

(2000). "Foreword" in Emekwu. H. (2000). Democracy and Religion: Sharia in Nigeria. Enugu: Snaap Press Ltd.

Obiora, F. K. (1998). The Divine Deceit: Business in Religion. Nimo: Rex Charles and Patrick Ltd.

Odey, J. O. (2000). The Sharia and the Rest of Us. Enugu: Snaap Press Ltd. Okeke, V. M. (2008). Religion as a Socio-ethical Force in Igbo Society Today. Paper Read at the Conference of Igbo Religious Leaders, Nelrose Hotel, Asaba.

Okike, B.O.(2000). The Practice of Sharia in Nigeria: A Democratic Secular State. Enugu: Snaap Press Ltd.

Okwueze, M.I.(1998). "Religion as a Potential Instrument for Cultural Conflicts" in International Journal of Studies in Humanities (IJOSH), Vol.1 No. 1, July 1998, pp.136-143.

Okwueze, M. I. (ed.). (2004). Religion and Societal Development: Contemporary Nigeria Perspectives. Lagos: Merit International Publications.

Omotola, J. S. (2009). Secularism and the Politics of Religious Balancing in Nigeria. Mowe: Redeemer's University Redemption City. (pdf).

Onah, G (1998). "Democracy as an Illusion" in Oguejiofor, J. O. (ed) (1998). Africa:Philosophy and Public Affairs.

Onwukeme, V. (2010). "The Law as a Baby Sitter: An Exposition of Romans 3: 27-31" in

Obanure, C \& Nwachukwu, M. S. (eds.) (2010). Cathan: A Searchlight on St.

Paul. Makurdi: Aboki Publishers.

Oraegbunam, I.K.E (2005). "Religion as a Factor of Social Development" in Journal of Arts and Humanities, vol. 2, No. 2.

-(2005). "Separation of Powers and Nigerian Constitutional Democracy". Retrieved on 20/4/2010 from http://www.dawodu.com/oraegbunamlhm. (2010). Adoption of Islamic Criminal Law and the Principle of State Secularity in Nigeria. Unpublished paper submitted for the journal of religion, University of Nigeria, Nsukka.

Ozigbo, I.R.A. (1988). An Introduction to the Religion and History of Islam. Enugu: Fourth Dimension Publishers.

Procter, P. (ed.) (1980). Longman Dictionary of Contemporary English. London: Longman Group Ltd. 
Ryu, S. (2009). Limits on Secularism in Korean Constitution. Korea: Pusan University of Foreign Studies. (pdf).

Sàid, M. I. (2003). "Sharia and the Constitution: Legal Issues in Perspectives" in Oseni, Z.I. (ed.) (2003). A Digest on Islamic Law and Jurisprudence in Nigeria. Auchi: Darun - Nur, pp. 189-197

Sauter, G. (1982). Religion in Tradition and Change of Society" in Abdullah, M. S., Erl, W. \& Khoury, A. T. (eds) (1982). Religion in Culture, Law and Politics. Germany: V. Hase \& Koehler.

Schineller, P. (ed.) (2002). The Voice of the Voiceless. Ibadan: Daily Graphics Nig. Ltd.

Simpson, D. P. (1962). Casell's New Latin-English English-Latin Dictionary. London: Cassell.

Smart, N. (1984). The Religious Experience of Mankind. New York: Charles Scribner's Sons.

Stamer, P. J. (1995). Islam in Sub-Saharan Africa. Spain: Editorial Verbo Divino.

Streng, F. Lloyd, C \& Allen, J. (1973). Ways of Being Religious. New Jersey: Prenticehall, Inc.

Stumpf, S.E. (1993). Philosophy: HHistory and Problem, New York: McGraw-Hill, Inc.

The Oxford Pocket Dictionary of Current English (2009). Democracy. Retrieved on 23/12/09 from http://www.encyclopedia.com/doc/10999-democracy.html.

Ubaka, C. O. (2000). Sharia in Nigeria: its Implications for Non-Muslims. Engugu: Snaap Press Ltd.

Ugwu, C. O. T. (2004). "Salient Igbo Moral Values as the Fulcrum of Societal Development" in Okwueze(2004)....pp. 287-296.

Uthman, M. B. (2003). "Protecting the Rights of Accused Persons through the Proper Implementation of the Sharia Procedural Guarantees in Northern Nigeria" in Ezeilo, J. N., Ladan, M. T. \& Afolabi - Akiyode, A. (eds) (2003). Sharia Implementation in Nigeria...,pp. 171-205.

Weber, M. (1968). The Protestant Ethic and Spirit of Capitalism. New York: Scribners.

Wikipedia, the Free Encyclopedia. (2009). Islam. Retrieved on 6/1/2010 from http://en..wikipedia.org/wiki/islam.

Yinger, M. (1969). Religion, Society and the Individual. Canada: The Macmillan Company. 
Public Co.

Zarifis, I. (2010). "Rights of Religious Minorities in Nigeria" in Human Rights Brief, vol. 10 Issue 1. Retrieved on $7^{\text {th }}$ April, 2010 from http: //www.statemaster.com/encyclopedia/secular-state. 